\title{
Lidská důstojnost jako základ vztahu mezi pacientem a lékařem
}

\section{Martina Pavelková}

\author{
Život je krátký, \\ umèní dloubé, \\ príležitost prchavá, \\ zikušenost klamná, \\ rozbodnutí tě̌̌ké. \\ (Hippokratés) $^{1}$
}

\section{Úvod}

Vztah mezi lékařem a pacientem prošelv dějinách medicíny určitým vývojem. VHippokratově př́saze čteme, že nejdůležitější je zdraví pacienta (salus aegroti suprema lex). Postupně se však začal prosazovat př́stup, který do popředí staví autonomii pacienta (voluntas aegroti suprema lex). $\mathrm{V}$ posledních desetiletích se vztah mezi lékařem a pacientem zkomplikoval nejen pokrokem $\mathrm{v}$ medicíně, ale také čím dál větším očekáváním pacientů. Dřive bylo přirozené, že některá onemocnění jsou považována za nevyléčitelná. Dnes je nevyléčení těchto nemocí chápáno jako selhání kurativní medicíny. Pacienti se odmítají smírit s nepř́znivou diagnózou a hledají viníka, který by byl odpovědný za jejich stav. Na vině jsou mnohdy i lékaři, kteří vzbuzují naděje na neomezené možnosti medicíny (někdy pouze proto, že sami sobě nejsou schopni přiznat, že jejich léčba selhala, že už nemohou pacientovi nic nabídnout).

V tomto př́spěvku se chceme zamýšlet nad vztahem mezi pacientem a lékařem, a to především s ohledem na situaci v této oblasti v České republice, která je vymezena př́slušnými zákony. Chceme přitom ukázat dějinnou proměnlivost vztahu mezi pacientem a lékařem, která je do značné míry dána pojetím zdraví a nemoci daného dějinného období. Předestřeme také $\mathrm{v}$ současnosti zastávané modely vztahu mezi pacientem a lékařem. Zvýrazníme tím obtíže a možnosti tohoto vztahu, přičemž za rozhodující základ jeho kvality považujeme lidskou důstojnost.

\section{Vztah lékaře a pacienta - záležitost etiky, či práva?²}

Když se dnes pojednává o vztahu lékaře a pacienta, většinou se myslí především právní aspekt tohoto vztahu. Lékař musí pacienta poučit o svém postupu a vyžádat si informovaný souhlas. V opačném př́padě by se mohl dostat do sporu se zákonem. Existuje mnoho právních norem, které ošetřují vztah mezi lékařem a pacientem. Přitom počet norem, které se snaží pokrýt složitost tohoto vztahu, neustále roste. Zatímco dříve se zdravotnická

1 Hippokratův aforismus je starý více než 2500 let a v hutné podobě pokrývá různé aspekty medicíny: Lékařské umění je založeno na zdlouhavém a v podstatě nikdy neukončeném získávání poznatků; současně závisí na správném okamžiku, který však rychle pomíjí; je založeno na pokusech, které nejsou jisté. Kvůli tomu všemu je v medicíně velmi obtížné učinit správné rozhodnutí. 2 Samožrejmě se nabízí také pohled ekonomie, protože pacient si za služby lékaře platí (minimálně prostřednictvím povinného zdravotního pojištění). Ekonomický aspekt, byt' není nevýznamný, zde však zůstává stranou našeho zájmu. 
problematika vyskytovala $\mathrm{v}$ právu spíše okrajově, dnes se už hovoř́ o zdravotnickém právu jako samostatném odvětví práva. ${ }^{3}$ Právník Tomáš Doležal analyzoval vztah mezi lékařem a pacientem $z$ právně-historického hlediska a došel $k$ závěru, že tento vztah má soukromoprávní povahu. $V$ předmluvě ke své knize uvádí, že ji psal v době př́íprav změny zákona 20/1966 Sb., o péči o zdraví lidu - zákon o zdravotních službách. Během těchto př́prav pronikaly na veřejnost informace o tom, že starý zákon „nevyhovuje modernímu pojetí vztahu lékaře a pacienta, je př́lišs paternalistický a nedbá autonomie obou zúčastněných subjektů - zkrátka je projevem etatismu 70. let v ČSSR““. ${ }^{4}$ Dalo by se tedy logicky očekávat, že se připravovaný nový zákon odkloní od tohoto veřejnoprávního pojetí. To se však nestalo, ani nový zákon č. 372/2011 Sb., o zdravotních službách př́liš nezměnil pohled na vztah mezi lékařem a pacientem, který je i nadále nahlížen ve veřejnoprávní rovině. ${ }^{5}$ Lékař je ve své každodenní praxi konfrontován s řadou právních regulací, které jsou však mnohdy promítnutím (bio)etických norem do oblasti práva. Samozřejmě existují etické kodexy a úmluvy, které však - pokud nejsou právně vymahatelné - nejsou ze strany lékařu brány př́liš vážně. Současná legislativa, která upravuje poskytování zdravotnické péče, stojí na základních etických principech, jako je salus aegroti suprema lex (zdraví pacienta je nejvyšším zákonem) nebo voluntas aegroti suprema lex (vůle pacienta je nejvyšším zákonem). Druhý př́stup se začal prosazovat pozvolna spolu s důrazem na lidská práva a autonomii jedince. Pro lepší pochopení vztahu mezi lékařem a pacientem si načrtneme dějinné proměny, kterými tento vztah prošel.

\section{Proměna vztahu mezi lékařem a pacientem}

V antice, středověku a novověku se vnímání nemoci a zdraví - a od toho se odvíjející podoba vztahu mezi lékařem a pacientem - velmi proměňovaly. Různé filosofické názory a etické zásady ovlivňovaly medicínu po staletí až do dnešních dnů. Ve stručnosti si popišme hlavní rysy typické pro každou epochu. ${ }^{6}$

V antice hrála zásadní roli kosmologie. Vztah člověka k vlastnímu tělu byl ovlivněn jeho vztahem $k$ prŕrodě. Obraz člověka a prírody určoval představu o zdraví a nemoci. Vztah mezi lékařem a pacientem je pro tuto dobu př́iznačně vyobrazen na starořímském pohřebišti v Ostii. Najdeme zde obraz ženy, která rodí své dítě do rukou jiné ženy a současně je zezadu podpírána další ženou. Tento obraz je symbolem pomoci člověka člověku v konkrétním okamžiku jeho života. Na takto zobrazené lékařské umění myslel lékařViktor von Weizsäcker, když ve 20. století řekl: „Základním obrazem medicíny je jednak člověk v nouzi, jednak

\footnotetext{
3 O postupném pronikání zdravotnických témat do oblasti práva velmi výstižně píše rakouský právník Gerhard Köbler ve svém článku Od lékaře v právu k lékařskému právu. Za zlomový přitom považuje rok 1977, kdy právník Adolf Laufs vypracoval spis čítající 110 stran s názvem „Arztrecht“. Srov. Gerhard KÖBLER, Vom Arzt im Recht zum Arztrecht, in: Humaniora: Medizin - Recht Geschichte, Bern-Rüdiger KERN a kol., Berlin-Heidelberg: Springer-Verlag, 2006, s. 157-172.

4 Srov. Tomáš DOLEŽAL, Vżtab lékaře a pacienta zpobledu soukromébo práva, Příbram: Leges, 2012, s. 9.

5 Pro úplnost dodejme, že tento nový zákon se ještě před svou účinností stal předmětem několika ústavních stížností; po nabytí účinnosti se o jeho další novelizace snažila Česká lékařská komora, Svaz pacientů ČR a Senát ČR. Přibližně po roce od nabytí účinnosti byl zákon novelizován (úprava se týkala především poskytování zdravotních služeb nezletilým).

6 Zde se budeme opírat především o následující díla: Dietrich von ENGELHARDT, Die Arzt-Patient-Beziehung - gestern, heute, morgen, in: Die Arzt-Patient-Beziebung im Wandel, ed. Klaus ARNOLD, Stuttgart: Thieme, 1996, s. 19-47; Dietrich von ENGELHARDT, Das Bild des Arztes in medizinhistorischer Sicht, in: Arat - Patient. Zur Geschichte und Bedeutung einer Beziebung, Tübingen: Attempto, 2001, s. 31-42.
} 
člověk, který pomáhá. “7 Vztah mezi lékařem a pacientem se nejlépe odrazil v Hippokratově prŕsaze, která se na mnoho staletí stala pro chování lékaře určující. Lékař měl mít respekt před osobou nemocného a neměl rozlišovat mezi dítětem či starým člověkem, ženou či mužem, svobodným či otrokem. Toto pojetí odpovídalo křestanskému chápání rovnosti všech před Bohem. Ostatně také samotné zdraví a nemoc bylo v antice chápáno jako fyzický a současně náboženský fenomén, nebot medicína a filosofie se vzájemně ovlivňovaly. Zdraví a nemoc nebyly vnímány pouze jako smyslově zakusitelné stavy, nýbrž měly i své filosofické důsledky.

Pro středověkou medicínu je zásadním pojmem transcendence. To znamená, že kosmologicko-antropologický př́stup je podřízen teologické perspektivě. Podle tohoto pojetí Bůh dopouštěl nemoc jen tehdy, pokud to bylo prospěšné duši člověka. Nemoc tak byla podřízena poslednímu cíli člověka, byla chápána současně jako šance. Zdraví a nemoc tak získávají dějinně spásný význam. Jsou vztaženy na eschatologický pohyb směrem z ráje (constitutio) skrze pozemskou existenci (destitutio) ke vzkřrišení (restitutio). Skrze nemoc a uzdravení každý člověk sám na sobě uskutečňuje tento univerzální proces. Nemoc je vnímána jako nutná součást pozemské existence a je třeba mít na paměti, že přes veškerou snahu člověka není možné zde na zemi být zcela zdráv. Ke konečnému a úplnému uzdravení člověka dojde až skrze jeho spásu. Takovému chápání odpovídá rovněž vztah lékaře a pacienta. Zatímco lékař je obrazem Krista (Christus medicus), který uzdravuje, nemocný se stává obrazem Kristova utrpení. Lékař i pacient musí přijmout, že k pozemskému životu nutně patří nemoc, utrpení a smrt. Ideál dokonalého zdravotního stavu je pouhou iluzí a dlužno ř́ci, že iluzí dosti nebezpečnou. ${ }^{8}$

V novověku se začíná utvářet nový obraz medicíny, kterým jsme silně ovlivněni dodnes. Nemoc se stává předmětem lékařsky objektivní analýzy. $S$ postupnou sekularizací se nemoc začíná chápat jako narušení funkce orgánů, jako ztráta individuálních a sociálních schopností. Francis Bacon (1561-1626) na počátku novověku předpovídal velký pokrok medicíny, která by si měla poradit s nemocemi. René Descartes (1596-1650) přirovnal nemocného člověka $\mathrm{k}$ mechanickým hodinám, které nefungují. Lidské tělo a přírodu vůbec chápal mechanisticky: podobně jako hodiny jsou složené z koleček a závaží, tak i lidské tělo je jakýmsi druhem stroje, který je poskládán z kostí, nervů, svalů, cév, krve a kůže. Nemoc je prostě pojímána jako objektivní danost. Symbolem objektivizace nemoci se následně stal vynález teploměru. Technické chápání nemoci jako defektu organismu samozřejmě poznamenalo také vztah mezi lékařem a pacientem. Pacient-stroj se stal objektem, který byl lékařem-opravářem zkoumán, měřen, popisován a opravován.

Nutno však uvést, že později se opět začaly ozývat hlasy volající po zlidštění vztahu mezi pacientem a lékařem, jehož ideální podobu jsme viděli zachycenou na obrazu ve starořímském pohřebišti v Ostii. Jako jsme náš stručný dějinný přehled obrazem začínali, tak jej také obrazem můžeme nyní uzavřít. Španělský malíř Francisco Goya v jednom ze

7 Claus BUDDEBERG (ed.), Psychosoziale Medizin, Berlin-Heidelberg: Springer-Verlag, 2004, s. 345.

8 Vidíme zde rozdíl oproti současnému bipolárnímu chápání zdraví a nemoci - viz definici zdraví Světové zdravotnické organizace (WHO) jakožto stav komplexní fyzické, sociální a psychické pohody. Tato definice je př́liš maximalistická a vytváŕi jakousi utopistickou představu zdraví. Nutno říci, že málokdo dosahuje ve svém všedním životě stavu „komplexní pohody“. Na definici WHO se tedy musíme dívat spíše jako na ideál, ke kterému je třeba se přibližovat, aniž by jej bylo dosaženo. 
svých děl zachytil základ každého vztahu na poli medicíny (viz výše zmíněná slova Viktora von Weizsäckera) - na jedné straně je člověk v nouzi, na straně druhé člověk, který poskytuje pomoc. Na obraze Goya zachytil sebe sama s doktorem Arrietou. Goya jako pacient sedí na lůžku a rukama se přidržuje pokrývky, zatímco zezadu je podpírán svým lékařem, který mu nepodává žádné tabletky, nýbrž sklenici čisté vody. Hlavním úkolem lékaře má tedy být doprovázení nemocného, být mu na blízku v době nemoci. Dějinný exkurz vztahu mezi lékařem a pacientem můžeme nakonec zakončit slovy Karla Jasperse, který se mimo jiné velmi zasazoval o éthos v medicíně: „Lékař není ani technik, ani spasitel, je bytím pro druhého, je pomíjivou bytostí, která realizuje spolu s druhými, v druhých a v sobě samém svobodu a důstojnost, které považuje za základní kritéria."

\section{3. Čtyři modely vztahu mezi lékařem a pacientem}

$\mathrm{Na}$ samém začátku jsme předestřeli, jak důležitá je spolupráce mezi lékařem a pacientem. Následně jsme zmínili dějinné proměny této spolupráce lékaře a pacienta. Mezi oběma subjekty vztahu dochází $\mathrm{k}$ různým interakcím, které bychom mohli na základě jejich různé povahy zobecnit na čtyřech modelech. ${ }^{10}$

\section{Paternalistický model}

První model se též někdy nazývá „otcovský “11 nebo „kněžský“"12, nebot lékař zde plní úlohu toho, kdo nejlépe ví, co je pro zdraví a spokojenost pacienta nejlepší. Na základě svých znalostí posoudí pacientovu situaci a navrhne léčbu, která je vzhledem ke zdravotnímu stavu nejlepší. Paternalismus může být definován jako „záměrné opomenutí preferencí nebo jednání jedné osoby jinou osobou, když ta osoba, která tyto preference a jednání opomíjí, zdůvodňuje svoje jednání prospěšností nebo zabráněním škod osobě, jejíž preference nebo jednání byly opomenuty “" ${ }^{13}$ Paternalismus se ještě může dělit na silný a slabý. Ve slabém paternalismu lékař jedná $s$ úmyslem odvrátit škodu pacienta $\mathrm{v}$ prípadě, kdy tento není schopen ryze autonomního jednání (jde o osoby, které nejsou přiměřeně poučeny o svém stavu, osoby trpící těžkou formou deprese nebo osoby, které nejsou z různých důvodů schopny učinit svobodné rozhodnutí - např. jsou pod vlivem závislosti). Př́i silném paternalismu lékař zasahuje do jednání pacienta, ačkoli tento je přiměřeně informován, je autonomní a jedná dobrovolně.

\section{Informativní model}

Druhý typ vztahu mezi lékařem a pacientem ilustruje informativní model, který lze též nazvat jako „vědecký “ 14 či „inženýrský “15. V tomto modelu úloha lékaře spočívá v tom, že pacientovi poskytne informace ohledně jeho stavu a možných zákrocích včetně možných rizik s nimi spojených. Pacient si následně sám vybere postup, který sám chce, a úkolem

9 Karl JASPERS, Ein Beispiel: ärztliche Therapie, in: Philosophie, sv. 1, Berlin, 1932, s. 121-129.

10 Srov. např. Ezekiel J. EMANUEL - Linda L. EMANUEL, Four models of the physician-patient relationship, The Journal of the

American Medical Association 16/1992, s. 2221-2226.

11 Gilman BURKE, Ethic and medical decision-making, Primary Care 7/1980, s. 615-624.

12 Robert M. VEATCH, Models for ethical medicine in a revolutionary age, Hastings Cent Report 2/1972, s. 3-5.

13 Tom L. BEAUCHAMP, James F. CHILDRESS, Principles of Biomedical Ethics, New York: Oxford University Press, 2001 , s. 176.

14 Gilman BURKE, Ethics and medical decision-making, s. 615-624.

15 Robert M. VEATCH, Models for ethical medicine in a revolutionary age, s. 3-5. 
lékaře je pouze vykonat vybraný zákrok. Lékař je v tomto modelu chápán pouze jako jakýsi poskytovatel služeb. V tomto modelu je zřejmý rozdíl mezi fakty a hodnotami. Povinností lékaře je seznámit pacienta se všemi dostupnými fakty a pacient si následně sám vybere postup léčby, který nejlépe odpovídá hodnotám, které vyznává. Hodnoty, které zastává lékař, zde nehrají žádnou roli. Lékař se tak ocitá v roli jakéhosi technického odborníka, který pouze dbá na to, aby pacientovo poznání bylo co nejúplnější.

\section{Vysvětlující model}

Ve třetím modelu jde o to, aby lékař poznal hodnoty, postoje a přání pacienta a pomohl mu ze všech dostupných řešení nalézt to, které nejvíce těmto hodnotám odpovídá. Podobně jako $\mathrm{v}$ předcházejícím modelu musí lékař pacienta seznámit $\mathrm{s}$ povahou, podmínkami, výhodami a riziky léčebného postupu. Ovšem u vysvětlujícího modelu jde též o to, aby lékař pacientovi př́padně pomohl vyjádřit či ujasnit si žebříček hodnot. Lékař zde tedy také plní funkci psychologa či psychoterapeuta, protože někdy může být velmi obtížné dopátrat se hodnot zastávaných pacientem, a je tedy třeba zkoumat dosavadní pacientův život a zjistit jeho priority. Pacient zde svou autonomii realizuje tím, že si lépe uvědomí svou identitu a zvolí si řešení, které nejlépe respektuje jeho osobnost.

\section{Deliberativní model}

Poslední model klade na lékaře největší nároky. Úkolem lékaře je angažovaně doprovázet pacienta celým procesem rozhodování a pomoci mu dospět k rozhodnutí, které bude nejlépe odpovídat zdravotnímu stavu pacienta a jeho hodnotám. Lékař s pacientem společně rozvažují o tom, jakými hodnotami by se pacient mohl nebo měl řídit při výběru nejlepšího řešení své situace. V tomto modelu bychom lékaře mohli přirovnat k př́teli, který v dialogu hledá, co je pro pacienta nejlepší. Lékař nejenže předestírá možnosti, pro které se pacient mưq̆e rozhodnout, dokonce by mèl pacientovi poradit, pro jaké řešení by se mèl rozhodnout. Pacientova autonomie spočívá v mravním sebeurčení, protože pacient pouze nenásleduje své preference a hodnoty, nýbrž je ochoten - skrze dialog s lékařem - tyto hodnoty vzájemně porovnávat a zvažovat jejich dopad na léčebný proces.

Pokud bychom nyní všechny čtyři modely porovnali, zjistíme, že každý z nich nějakým způsobem počítá s pacientovou autonomií, avšak liší se jejím chápáním.

\section{Autonomie a informovaný souhlas pacienta}

Jak je patrné $\mathrm{z}$ předchozích řádků, autonomie patří $\mathrm{k}$ ústředním pojmům medicínské etiky. Zásadní význam pro vytvoření etického chápání pojmu autonomie má praktická filosofie Immanuela Kanta (1724-1804). V návaznosti na Kantovu filosofii je v oblasti etiky autonomie vnímána jako svobodné vědomí člověka, ve kterém se lidská zodpovědnost stává nutným předpokladem normativní závaznosti. ${ }^{16}$ Zjednodušeně bychom mohli říci, že autonomie spočívá ve svobodné vưli pacienta (v úvodu tohoto textu byla zmínka o etickém principu,

16 Pojem autonomie se však používá též v jiných disciplínách (politika, psychologie, právo, pedagogika, sociologie), kde má poněkud jiný význam. K různým významům pojmu autonomie srov. Monika BOBBERT - Micha H. WERNER, Autonomie/Selbstbestimmung, in: Handbuch Etbik und Recht der Forschung am Menschen, C. LENK a kol., Berlin-Heidelberg: Springer-Verlag, 2014, s. 105-114. 
podle nějž je vůle pacienta nejvyšším zákonem). Českému čtenáři znalému právní úpravy nezní výraz „vưle pacienta“ př́liš důvěrně. Do roku 1989 se o vůli pacienta v podstatě nedá hovořit. ${ }^{17}$ Teprve $\mathrm{v}$ roce 2001 se autonomie pacienta dostává do našeho právního řádu v souvislosti s přijetím Úmluvy o lidských právech a biomedicíně. Nacházíme ji zde $\mathrm{v}$ podobě institutu informovaného souhlasu pacienta. Je však nutné si uvědomit, že právní normou nelze automaticky změnit hodnotový př́stup lékaře k pacientovi. Každý lékař je ze zákona povinen před zamýšleným zákrokem získat pacientův informovaný souhlas. Ovšem respekt $\mathrm{k}$ autonomii pacienta vyžaduje nejen získání informovaného souhlasu, nýbrž též zapojení pacienta do samotného procesu rozhodování. V praxi je prosazování informovaného souhlasu stále obtížné (přestože - nebo možná právě proto - je přijetí institutu informovaného souhlasu vynucováno právní úpravou). ${ }^{18}$ Podle Tomáše Doležala z toho plynou dva problémy: a) informovaný souhlas je v praxi ze strany lékařu vnímán jako administrativní překážka při péči o pacienta (tato skutečnost je dobře vidět na nahrazování pohovorů mezi lékařem a pacientem přečtením předtištěného formuláře, který pacient ve svém stavu často podepíše, aniž by věděl, o co se vlastně jedná), b) právní teorie zcela bezvýjimečně lpí na institutu informovaného souhlasu, aniž by brala v potaz dílčí změny, které jsou nutné, má-li být informovaný souhlas udržitelný. Vzhledem k tomu, že Česká republika je oproti západním zemím značně opožděna $\mathrm{v}$ přijetí informovaného souhlasu, musíme jednak řešit problémy, které byly ve vyspělejších zemích již vyřešeny, jednak nestíháme reagovat na podněty, které s sebou přináší prudký rozvoj medicíny a které významně upravují chápání informovaného souhlasu. ${ }^{19}$ Nacházíme se v období, ve kterém byly Spojené státy v letech 1957 až 1972 a které Beauchamp s Fadenem nazývají Becoming Informed About Informed Consent („období, kdy se utváří vědomí informovaného souhlasu“) ${ }^{20}$ Mezitím si právní teorie ve spojení s biomedicínou v západních zemích uvědomily problém, který může ohledně informovaného souhlasu vyvstat $\mathrm{v}$ souvislosti s bourlivým rozvojem lékařské vědy. Došlo tedy k období, které bychom mohli nazvat Rethinking Informed Consent („období, kdy se znovu promýšlí informovaný souhlas“), ${ }^{21}$ ve kterém je pojem informovaného souhlasu přehodnocován, protože se ukazují problémy, které není možné řešit $\mathrm{v}$ rámci partnerského vztahu mezi pacientem a lékařem. Otevírá se před námi situace, kdy se vracíme k pojmu paternalismu či neopaternalismu. Důvodem je fakt, že rozhodnutí pacienta nikdy nemůže být zcela autonomní, nebot jeho svoboda může být determinována následujícími faktory: ${ }^{22}$

\footnotetext{
17 Dobře je tato situace ilustrována v komunistickém kultovním seriálu Nemocnice na kraji města, kde se zraněný hokejista Přemysl Rezek dožaduje vysvětlení léčebného postupu, který jej čeká, aby se mohl rozhodnout, zda k jeho provedení dá svůj souhlas. Přijde k němu operující lékař a umlčí jej slovy „Jaký souhlas? My ti tu hlavu prostě spravit musíme."

18 Ve Spojených státech byl proveden výzkum jak mezi praktickými lékaři, tak i mezi odbornými specialisty ohledně jejich motivace pro získání pacientova informovaného souhlasu, který podle tamějších zákonů musí lékař získat před provedením léčebného zákroku. Bylo zjištováno, jaká mají od tohoto jednání očekávání, jaký je jejich postoj k pacientově účasti a co si myslí o povaze rozhodovacího procesu. Podle výsledků výzkumu většina lékařů vítá zapojení pacientů do procesu rozhodování. Pacientova spoluúčast na rozhodování je totiž chápána jako logický důsledek jeho autonomie. Ovšem dalším častým důvodem pro zapojení pacienta je též princip beneficence či vlastní zájem lékaře vyhnout se možné žalobě ze strany pacienta. Srov. Amy L. McGUIRE - Laurence B. McCULLOUGH - Susan C. WELLER - Simon N. WHITNEY, Missed Expectations? Physicians' Views of Patients' Participation in Medical Decision-Making, Medical Care 5/2005, s. 466-470.

19 Srov. Tomáš DOLEŽAL, Problematické aspekty vztahu lékaře a pacienta zejména s ohledem na institut tzv. informovaného souhlasu, Časopis zdravotnického práva a bioetiky 1/2011, s. 25-35.

20 Srov. Tom L. BEAUCHAMP - Ruth R. FADEN, A History and Theory of Informed Consent, Oxford - New York: Oxford University Press, 1986, s. 88-100.

21 Srov. Jaime S. KING - Benjamin MOULTON, Rethinking Informed Consent: The Case for Shared Medical Decision- Making, American Journal of Law \& Medicine 32/2006, s. 429-501.

22 Srov. Tomáš DOLEŽAL, Problematické aspekty vztahu lékaře a pacienta, s. 25-35.
} 
- Pacientův stav - pacient se na lékaře obvykle obrátí v situaci, kdy mu není dobře, kdy není zdráv. ${ }^{23}$ Adam Doležal tento stav popisuje výstižně těmito slovy: „Pacient se nachází $\mathrm{v}$ pozici strachu, nejistoty a bolesti. Možnost bytí jeho Já je omezována vnějším útokem nemoci, spojené s bolestí, a tak se nechává uchopit jinou existencí, které svěřuje své já. Oproti tomu je lékařovo postavení uchopující, v opakovaném úkonu někdy i rutinní, sice vedené s maximálně odbornou péčí, nicméně bytostně nezaujaté. Lékař je tak v pozici, která je oddělená od bytostného chápání úzkosti Druhého Já, tj. pacientovy existence. ${ }^{24}$

- Nemožnost zcela objektivního sdělení - lékař, který má pacientovi poskytnout informaci, je nějakým způsobem ovlivněn výchovou, náboženským vyznáním, vzděláním. Proto se můžeme ptát, zda ,informace o účelu a povaze zákroku, jakož i o jeho důsledcích a rizicích je pacientovi podávána vždy v čisté formě. Tato informace je totiž vždy podávána osobou, kterájiž má vytvořený určitý názorový rámec na danou věc, a z tohoto hlediska její informace nemůže být čistým objektivním oznámením faktu, naopak je již prezentována jako předvybrané stanovisko. I kdyby se lékař snažil být jakkoliv objektivní, nikdy nevystoupí ze svého světa. Ač tedy normativní systémy (právní i etický, vyjádřený stavovským kodexem) vyžadují informování rááné, tj. o všech možnostech, a nezaujaté, takovéto poskytnutí informace není v reálném mimonormativním světě možné." 25

- Lékař je více odborně vzdělán než pacient, což $\mathrm{v}$ praxi vede $\mathrm{k}$ tomu, že pacient většinou přijme léčebný postup navržený lékařem.

- Objektivizace medicíny - díky rozvíjející se technice a stále častějším zákonným úpravám v medicíně se stále více zmenšuje možnost, kdy lékař může uvažovat samostatně a plně se věnovat pacientovi, ve kterém vidí především člověka, a nikoli další medicínský př́ípad.

- Úzká specializace lékaře - každý lékař je odborníkem ve své vlastní disciplíně, avšak často schází přesah do ostatních oborů, takže informace, které lékař pacientovi poskytuje, mohou být poznamenány úzkou specializací v daném oboru.

Z výše uvedeného je zřejmé, že institut informovaného souhlasu, který se sotva stačil zabydlet $\mathrm{v}$ našem právním řádu, s sebou nese mnohá úskalí, která se nutně promítají do vztahu mezi lékařem a pacientem.

\section{Důstojnost jako základ vztahu mezi pacientem a lékařem}

Viděli jsme, že vztah lékaře a pacienta je poznamenán jistou asymetrií. Lékař na jedné straně pacientovi pomáhá a na druhou stranu odkrývá člověku jeho tajemství, odhaluje jeho

\footnotetext{
23 Samostatným tématem jsou psychiatricky nemocní pacienti. V těchto př́padech se do konfliktu dostává princip péče a respekt k pacientově autonomii. Podrobněji o těchto situacích srov. Martin Hans SASS, Advance Directives for Psychiatric Patients? Balancing Paternalism and Autonomy, Wiener Medizinische Wochenschrift 17-18/2003, s. 380-384.

24 Adam DOLEŽAL, Informovaný souhlas jako vyjádření autonomie vůle nebo reflexe paternalistického vztahu?, Casopis zdravotnickébo práva a bioetiky 1/2011, s. 8.

25 Tamtéž, s. 9 .
} 
nitro. Vyslovuje soudy, na nichž může záviset, zda člověk zemře, nebo bude žít. Podobně jako každý, kdo druhému prokazuje dobro, jsou také lékaři vystaveni vděčnosti i nenávisti zároveň. ${ }^{26}$ Kvůli používání technických prostředků, které přistupují $\mathrm{k}$ pacientům jako k objektům, se tato nenávist ještě zvětšuje.

Z pohledu etiky je potřeba se zaměřit na to, aby byl pacient vnímán a respektován jako subjekt a jako bomo absconditus. Když už nenávist jakožto antropologický existenciál nemůže být zcela odbourána, je třeba ji usměrnit tím, že nebudeme navyšovat očekávání pacientů a nebudou podporovány různé spasitelské fantazie. ${ }^{27} \mathrm{Je}$ třeba se snažit vytvářet prostředí důvěry mezi pacientem a lékařem. Důvěryhodnost a čestnost lékaře je jedním z etických témat, které je stále aktuální a jehož relevance je stále zdůrazňována. Za samozřejmý je považován fakt, že pacient by měl svému lékaři důvěřovat. Méně pozornosti je však věnováno důvěře, kterou by měl mít lékař vůči pacientovi. Př́tomnost nebo absence důvěry mají jak mravní, tak praktické důsledky. Filosofka Wendy Rogersová je přesvědčena, že lékaři dokonce mají povinnost svým pacientům důvěřovat. ${ }^{28}$ Je zřejmé, že lékař se do jisté míry musí spoléhat na pacienta. Je odkázán na jeho výpověd' o subjektivních potížích, na základě nichž navrhuje léčbu. Také $\mathrm{v}$ jejím průběhu se musí spoléhat na pacientovu spolupráci při léčbě a jeho líčení průběhu a zlepšení stavu. Samozřejmě výjimku tvoří situace, kdy pacient není schopen spolupracovat - $\mathrm{k}$ takovým př́padům může dojít např́klad v urgentní medicíně nebo v terminálním stadiu nemoci pacienta. Rogersová přrirovnává důvěru k čočce, která zabarvuje náš pohled. Pokud někomu důvěřujeme, tak jeho jednání interpretujeme ve světle této důvěry. ${ }^{29} \mathrm{~S}$ důvěrou je těsně spojen pojem empatie. Konkrétně se hovoří o „klinické empatii“, která by měla být „rámcem vědomostí a dovedností všech odborníků, kteří nějakým způsobem pečují o pacienty “. ${ }^{30}$ Vidíme, že oproti př́stupu orientovanému na nemoc (disease-centered care) stojí př́stup orientovaný na pacienta (patient-centered care). Zatímco se píší odborné články o empatii, v praxi stále převažuje objektivizující př́stup k pacientovi. ${ }^{31}$ Jaromír Matějek vidí problém již ve vzdělávání budoucích lékařù na lékařských fakultách, kde se ukazuje jisté napětí mezi medicínou a humanitními vědami. ${ }^{32}$

I když připustíme, že lékař se co nejvíce snaží respektovat pacientovu autonomii (prostřednictvím informovaného souhlasu a s minimalizací faktorů, které by mohly pacientovu autonomii ohrožovat), může dojít $\mathrm{k}$ situacím, kdy se pacient cítí být zraněn ve své důstojnosti. Miles Bore tuto situaci popisuje slovy: „Ačkoli člověk může svobodně souhlasit s lékařským postupem, být dostatečně informován o tomto postupu, mít chráněny

\footnotetext{
26 Kant ve svém díle Náboženství v branicích poubébo rozumu, ve 3. kapitole s názvem Člověk je od prirrozenosti špatný, píše o lidském sklonu nenávidět toho, komu jsme zavázáni. Srov. Immanuel KANT, Náboženství v branicích poubého rozumu, Praha: Vyšehrad, 2013, s. 75.

27 Srov. Knut BERNER, Der Hass auf die Wohltäter. Anthropologische und ethische Überlegungen zur Arzt-Patienten -Beziehung, Zeitschrift für medizinische Etbik 4/2012, s. 327-339.

28 Srov. Wendy A. ROGERS, Is There a Moral Duty for Doctors to Trust Patients?, Journal of Medical Etbics 2/2002, s. 77-80.

29 Srov. tamtéž, s. 77.

30 „...should frame the skills of all professionals who care for patients." Howard M. SPIRO, What is Empathy and Can It Be Taught?, in: Empatby and the Practice of Medicine: Beyond Pills and the Scalpel, Howard M. SPIRO - Deborah St. JAMES, Yale University Press, 1996, s. 7-14, zde s. 7.

31 Srov. Rebecca GARDEN, The Problem of Empathy: Medicine and the Humanities, New Literary History 3/2007, s. $551-567$.

32 Problémem je fakt, že na dnešních lékařských fakultách je medicína vnímána spíše jako aplikovaná biologie člověka. Lékař je pak vnímán spíše jako př́rodní vědec, který se orientuje na anatomii a fyziologické procesy v člověku, a poněkud mu unikají další významy nebo kontexty, které s sebou onemocnění člověka přináší. Srov. Jaromír MATĚJEK, Co je nemoc a proč si pacienti na nás pořád stěžují, Pediatrie pro praxi 1/2011, s. 51-52.
} 
údaje o svém stavu mlčenlivostí lékaře, přečkat lékařský zásah bez újmy a dokonce z něj mít prospěch, přesto v něm může být vyvolán pocit ztráty lidské důstojnosti. "33 Vidíme tedy, že pojem autonomie se ukazuje být nedostatečným pro postihnutí jádra vztahu mezi lékařem a pacientem. Jako užitečnější se ukazuje pojem lidské důstojnosti. ${ }^{34}$

Respektovat lidskou důstojnost znamená pohlížet na pacienta jako na „účel sám o sobě a nikoli jako na „prrípad“. Lidská důstojnost je nejvyšším morálním principem, který klade důraz na svobodné rozhodnutí pacienta, které je završením doprovázejícího vztahu mezi lékařem a pacientem. ${ }^{35}$

Je třeba rozlišit mezi pojmem inherentní a kontingentní důstojnosti. Inherentní důstojnost má každý člověk na základě faktu, že je člověkem. Nemůžeji ztratit, ani nemůže být umenšena či odňata. Nezáleží na tom, jaké má člověk postavení, jak je starý, bohatý či inteligentní. $\mathrm{Na}$ tomto konceptu důstojnosti jsou vystavěna lidská práva a rovnost všech lidí před zákonem. Kontingentní důstojnost je člověku naopak přisuzována zvnějšku na základě jeho schopností, vlastností či společenského postavení. Je zřejmé, že nemoc či utrpení mohou člověka zraňovat právě v tomto typu důstojnosti. Ačkoli člověk nikdy nemůže pozbýt svou inherentní důstojnost, může být velmi zraněn ve své důstojnosti kontingentní. Na to je třeba pamatovat ve vztahu mezi lékařem a pacientem především ve stadiu nemoci či obecně stáŕí, kdy člověk není schopen vykonávat funkce, které bez problémů zastal ve zdraví či mládí. ${ }^{36}$

\section{Závěr}

V tomto textu jsme se zabývali etickou stránkou vztahu mezi lékařem a pacientem. Viděli jsme, že tento vztah měl v minulosti spíše soukromoprávní povahu, která je v současnosti zastřena skrze stále narůstající právní regulaci vztahu mezi pacientem a lékařem. Etické principy se stávají vymahatelnými právními normami, což s sebou nese jisté obtíže především v oblasti institutu informovaného souhlasu, v jehož reflexi Česká republika zaostává za západními zeměmi a je nucena řešit problémy, se kterými se západní země potýkaly přibližně před padesáti lety. Vztah mezi lékařem a pacientem se v posledních desetiletích také zkomplikoval nejen pokrokem v medicíně, ale čím dál větším očekáváním pacientů. Dnes je nevyléčení nemocí, které $\mathrm{v}$ minulosti byly považovány za smrtelné, chápáno jako selhání kurativní

33 „While the person might voluntarily agree to a medical procedure, be well informed of the procedure, have their records of the procedure kept in strict confidence, be unharmed by the procedure and actually benefit from the procedure, they might still incur and feel a loss of dignity. “ (C) Miles R. BORE, Dignity: Not Useless, Just a Concept in Need of Greater Understanding, BMJ Rapid Responses, February 17, 2004 (on-line), dostupné na: http://www.bmj.com/rapid-response/2011/10/30/dignity-not -useless-just-concept-need-greater-understanding, citováno dne 28. 11. 2015.

34 Pojem důstojnosti získal na významu zvláště po 2. světové válce. V mezinárodním právu se stal standardem, kterým je vyjadřován respekt ke každému člověku ve všech oblastech jeho života. Medicínská oblast zřejmě patří mezi nejcitlivější oblast, a tak není divu, že pojem lidské důstojnosti zde hraje ústřední roli. Podrobněji k pojmu lidské důstojnosti v mezinárodní bioetické diskuzi srov. Roberto ANDORNO - Marcus DÜWELL, Der Menschenwürdebegriff in der Bioethik, in: Menschenwürde und Mediz̨in: ein interdisziplinäres Handbuch, ed. Jan C. JOERDEN, Berlin: Duncker \& Humblot, 2013, s. 465-481. Ne všichni autoři však přijímají koncept lidské důstojnosti jako nutný. Ruth Macklin se ve svém článku Dưstojnost je neužitečný pojem. Nežnamená nic víc než respekt $k$ osobě či její antonomii pokusila lidskou důstojnost redukovat na pouhý respekt k autonomii člověka, čímž pojem důstojnosti označila jako neužitečný s tím, že může být z bioetického diskurzu vypuštěn. Srov. Ruth MACKLIN, Dignity is a useless concept.

It means no more than respect for persons or their autonomy, BMJ 327/2003, s. 1419-1420.

35 Srov. Ottfried HÖFFE, Medizin obne Etbik?, Frankfurt am Main: Suhrkamp, 2002, s. 49.

36 Srov. též Marta MUNZAROVÁ, Důstojnost člověka a lékařská etika, Časopis lékařro českých 9/2011, s. 499-501; Marta

MUNZAROVÁ, Důstojnost člověka v kontextu lékařství, in: Etika a komunikace v medicíně, Praha: Grada Publishing, 2011, s. 51-58. 
medicíny. Pacienti získávají ambivalentní vztah ke svým lékařům, protože jsou jim na jednu stranu zavázáni a na druhou stranu k nim pocitují jistou nenávist. Na vině jsou však i lékaři, kteří vzbuzují naděje na neomezené možnosti medicíny (třeba proto, že nejsou schopni si připustit své vlastní omezené možnosti).

Způsobem, jak předcházet vzájemnému zklamání, je správná, otevřená komunikace mezi lékařem a pacientem. Tato komunikace by měla být založena na schopnosti důvěry, empatie a respektu k lidské důstojnosti pacienta. Lidská důstojnost je nejvyšším morálním principem, který respektuje svobodné rozhodnutí pacienta jakožto završení doprovázejícího vztahu mezi lékařem a pacientem. Pacient by měl být nahlížen jako jedinec $s$ vlastní vưlí, který potřebuje pomoci, a lékař by měl být vnímán jako odborník, který je tu od toho, aby se pacientovi snažil pomoci, nikoli mu způsobit škodu.

\title{
Lidská důstojnost jako základ vztahu mezi pacientem a lékařem
}

\begin{abstract}
Abstrakt
Článek reflektuje vztah mezi pacientem a lékařem, a to především s ohledem na zákon, který tento vztah upravuje v České republice. Je ukázána dějinná proměnlivost vztahu mezi pacientem a lékařem, která je do značné míry dána pojetím zdraví a nemoci daného dějinného období. Různé typy vztahu lékaře a pacienta Ize zobecnit na čtyřech modelech. Při pohledu na všechny obtíže a možnosti tohoto vztahu za rozhodující základ jeho kvality považujeme lidskou důstojnost.
\end{abstract}

Klíčová slova: lékař, pacient, vztah, lidská důstojnost, autonomie, informovaný souhlas

\section{Human Dignity as the Foundation of the Patient-Physician Relationship}

\begin{abstract}
This article reflects the relationship between patient and physician, mainly with regard to the Czech law. The concept of health and disease in each historical period also influenced the patient-physician relationship. Different kinds of this relationship are demonstrated on four models. When we reflect the relationship between physician and patient, with all its difficulties and possibilities, we recognize human dignity as the basis of this relationship.
\end{abstract}

Keywords: physician, patient, relationship, human dignity, autonomy, informed consent

\section{Kontakt na autora}

\section{Mgr. Martina Pavelková}

Jihočeská univerzita v Českých Budějovicích

Teologická fakulta, Katedra etiky, psychologie a charitativní práce

Kněžská 8, 37001 České Budějovice

Pavelkova.Martina@seznam.cz 